\title{
Restorasi Resin Komposit Menggunakan Pasak Tapered Self Threading Pada Molar Ketiga Kiri Mandibula
}

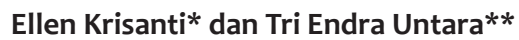 \\ * Program Studi Konservasi Gigi PPDGS Fakultas kedokteran Gigi, Universitas Gadjah Mada \\ ** Bagian Konservasi Gigi, Fakultas Kedokteran Gigi, Universitas Gadjah Mada \\ *JI Denta no 1 Sekip Utara No 1 Yogyakarta, e-mail: ellen_laurensia@ymail.com
}

\begin{abstract}
ABSTRAK
Morfologi saluran akar gigi molar mandibula ketiga memiliki variasi yang lebih kompleks dibandingkan gigi molar lainnya. Pada gigi molar ketiga sering dilakukan pencabutan, namun dalam keadaan tertentu gigi molar ketiga dapat dipertahankan. Perawatan saluran akar satu kunjungan merupakan pilihan untuk terapi kasus ini. Tujuan laporan kasus ini untuk memperlihatkan keberhasilan dari perawatan saluran akar satu kunjungan pada gigi molar ketiga nekrosis pulpa disertai restorasi resin komposit dengan pasak tapered self theading. Pasien wanita 20 tahun datang ke RSGM Prof Soedomo FKG UGM dengan keluhan sakit saat pengunyahan pada gigi molar ketiga dan positif pada perkusi. Gambaran radiografis menunjukkan restorasi yang tidak sempurna, terdapat celah antara kavitas dengan restorasi. Rencana perawatan pada kasus ini, perawatan saluran akar satu kunjungan dan resin komposit dengan pasak tapered self threading sebagai restorasi akhir. Kesimpulan dari perawatan saluran akar satu kunjungan memiliki rekontaminasi mikroorganisme yang lebih kecil dibandingkan dengan multi kunjungan sehingga menjamin keberhasilan perawatannya. Restorasi resin komposit secara direkdengan pasak tapered self threadingmerupakan restorasi alternatif pasca perawatan endodontikkarena lebih cepat dan kuat.
\end{abstract}

Maj Ked Gi. Juni 2013;20(1): 58 - 64.

Kata kunci : Perawatan saluran akar satu kunjungan, gigi molar ketiga mandibula, resin komposit, pasak tappered self threading.

\begin{abstract}
Composite Resin Restoration Using Tapered Self Threading Poston Left Mandibular Third Molar. Root canal morphology of mandibular third molar has more complex variation than the other molars. In third molar, the extraction teeth are often executed; however, the third molar can be maintained in other conditions. One visit root canal treatment is a therapy option for this case. The purpose of this case report is to show the success of one visit root canal treatment in third molar with pulp necrosis by restoring the composite resin through tapered self-treading post. A 20 year-old female patient who came to the Prof Soedomo RSGM, FKG UGM complained about the pain when chewing food on her third molar and positive in percussion. The radiographs showed that there was an incomplete restoration. There was a gap between cavities with restoration. The treatment plan for this case was one visit root canal treatment and composite resin with tapered self-threading post as final restoration. From the case, it can concluded that one visit root canal treatment results in a smaller chance for microorganism recontamination than the multi-visit in order to ensure the success of the treatment. Direct composite resin restoration with tapered self-threading dowel is an alternative restoration after endodontic treatment because it works out faster and more retentive.

Maj Ked Gi. Juni 2013;20(1): 58 - 64 .
\end{abstract}

Keywords: One visit root canal treatment, mandibular third molar, composite resin, tapered self-threading dowel.

\section{PENDAHULUAN}

Perawatan saluran akar merupakan perawatan yang memungkinkan dilakukan pada gigi insisivus sampai gigi molar terakhir. Konsepnya adalah mempertahankan gigi dengan akar gigi yang baik ataupun pada kondisi kelainan yang melibatkan jaringan periodontal. ${ }^{1}$ Perawatan saluran akar bertujuan untuk mengeliminasi bakteri dari dalam saluran akar sehingga akhirnya dapat mendukung terjadinya proses penyembuhan. Beberapa penelitian menunjukkan bahwa mustahil bagi operator untuk menciptakan saluran akar yang benar-benar steril, meskipun telah dilakukan proses cleaning, shaping dan irigasi dengan menggunakan bahan disinfektan maupun antiseptik. ${ }^{2}$ Mikroorganisme dalam saluran akar dapat bertambah dengan cepat hanya dalam waktu 2-4 hari jika dibiarkan dalam keadaan kosong. ${ }^{3}$ 
Banyak operator yang mencegah reinfeksi bakteri serta kontaminasi mikroorganisme dalam saluran akar dengan menggunakan kalsum hidroksida sebagai obat sterilisasi saluran akar antar kunjungan. Namun banyak penelitian yang menunjukkan bahwa kalsium hidroksida gagal menciptakan kondisi steril dalam saluran akar. Masih belum jelas kegagalan itu terjadi pada kasus apa saja, karena pemberian dressing antar kunjungan ataupun hasil kultur yang negatif tidak menjamin keberhasilan proses penyembuhan. ${ }^{4}$

Metode lain yang dapat digunakan untuk mengeliminasi kemungkinan rekontaminasi mikroorganisme dalam saluran akar adalah dengan menutup langsung saluran akar secara hermetis setelah preparasi dan irigasi pada satu kali kunjungan. ${ }^{3}$ Pengisian saluran akar yang hermetis dapat mencegah ruang mikroorganisme untuk berkembang biak. ${ }^{2}$ Keuntungan dari perawatan saluran akar satu kali kunjungan adalah waktu yang dibutuhkan lebih singkat, lebih bisa ditoleransi pasien dan menghindari rekontaminasi mikroorganisme saluran akar antar kunjungan. ${ }^{6}$

Faktor anatomi gigi dapat mempengaruhi keberhasilan dan kegagalan suatu perawatan saluran akar dengan mempertimbangkan bentuk saluran akar dan kelompok gigi. Bentuk saluran akar meliputi adanya pembengkokan, penyumbatan, saluran akar yang sempit atau bentuk abnormal akar lainnya, berpengaruh terhadap derajat kesulitan perawatan saluran akar yang dilakukan. ${ }^{7}$ Gigi molar ketiga mandibula biasanya mempunyai dua akar dan satu saluran atau tiga akar dan tiga saluran. Saluran akar biasanya pendek dan besar serta memiliki panjang rata-rata $18,5 \mathrm{~mm}$. Kamar pulpa gigi molar ketiga mandibula secara anatomis menyerupai kamar pulpa gigi molar pertama dan kedua mandibula. Kamarnya luas dan memiliki banyak konfigurasi anomalus seperti misalnya orifis saluran akar berbentuk C. ${ }^{5}$

Teknik crown down merupakan teknik preparasi saluran akar yang makin banyak digunakan. Teknik ini dapat menciptakan akses yang lurus sehingga akan meningkatkan penetrasi bahan irigasi ke dalam saluran akar, mengurangi hambatan di bagian korona sehingga memudahkan instrument mencapai daerah apeks, dapat mengurangi kemungkinan perforasi di apeks, dan dapat juga meminimalkan terdorongnya debris ke periapikal, serta memudahkan pengisisan saluran akar. ${ }^{7}$ Tujuan dari penulisan artikel ini adalah untuk melaporkan keberhasilan perawatan saluran akar satu kunjungan pada gigi molar ketiga mandibula dengan teknik crown down sistem rotary.

Gigi yang memerlukan perawatan saluran akar umumnya mengalami kerusakan pada jaringan pulpa dan mahkota, baik karena proses karies, restorasi sebelumnya atau trauma. Pasak yang dimasukkan ke dalam saluran akar dan inti yang terletak pada bagian supra gingiva berguna untuk menggantikan struktur gigi yang hilang serta mendukung restorasi pasca perawatan saluran akar. ${ }^{7} \quad$ Pasak tapered self threading lebih retentif daripada pasak halus atau pasak bergerigi sehingga dapat memperkuat restorasi resin komposit.

\section{STUDI KASUS}

Seorang pasien wanita datang ke klinik konservasi RSCM UGM pada tanggal 21 Februari 2013 ingin memeriksakan gigi belakang kiri bawah yang sakit, dan ingin menambal giginya. Pada

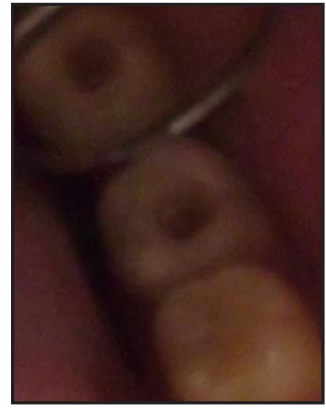

(A)

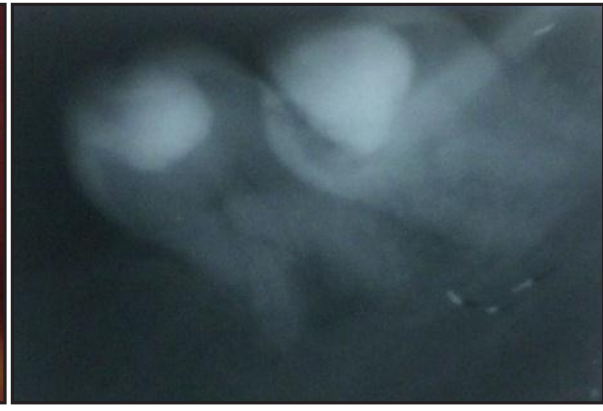

(B)

Gambar 1. (A) Gigi 38 setelah restorasi komposit kelas I dibuka;

(B) Restorasi tidak penuh, tampakada ruang yang tidak terestorasi . 
pemeriksaan objektif, terdapat gigi 38 karies kelas I dengan pulpa terbuka. Tes termal dengan chlor ethyl tidak menunjukkan reaksi, sedangkan pemeriksaan perkusi dan palpasi menimbulkan adanya reaksi dari pasien. Pada pemeriksaan radiografis, tampak restorasi tidak sempurna. Ada ruangan dalam kavitas yang tidak terisi oleh bahan restorasi (gambar 1B). Diagnosa kasus ini adalah gigi 38 nekrosis pulpa disertai periodontitis. Rencana perawatannya adalah perawatan saluran akar satu kunjungan gigi 38 dan restorasi resin komposit kavitas kelas II dengan pasak tapered self threading (dentatus screw). Prognosis pada kasus ini baik karena jaringan pendukung gigi cukup sehat, kebersihan mulut pasien baik, pasien sangat kooperatif, dan saluran akar lurus serta dapat dijangkau dengan peralatan saluran akar.

Pada kunjungan pertama, 21 Februari 2013, sebelum dilakukan perawatan, pasien diberi penjelasan mengenai prosedur rencana perawatan dan biaya serta waktu perawatan. Pasien menyetujui tindakan perawatan ini kemudian pasien menandatangani informed consent. Tindakan perawatan saluran akar: membuang sisa tumpatan komposit lama dengan round bur, jaringan karies yang masih tersisa dibersihkan dengan ekskavator dan digunakan bur akses untuk mencari orifis. Irigasi dilakukan dengan $\mathrm{NaOCl} 2,5 \%$ sebanyak 2,5 $\mathrm{ml}$ pada kavitas dan orifis yang sudah terbuka. Pengukuran panjang kerja estimasi dilakukan dari foto radiografis dengan cara panjang saluran akar pada foto radiografis dikurangi $1 \mathrm{~mm}$. Didapatkan panjang kerja estimasi saluran akar distal $16,5 \mathrm{~mm}$, mesiobukal $18 \mathrm{~mm}$, mesiolingual $18 \mathrm{~mm}$.

Negosiasi dilakukan untuk mendapatkan glide path saluran akar menggunakan file no 8 dan path file no 13 masing-masing untuk saluran mesiobukal, mesiolingual dan distal. Path file dimasukkan ke dalam saluran akar sepanjang 2/3 panjang kerja estimasi. Preparasi saluran akar menggunakan teknik crown down dan memakai protapper rotary (dentsply). Saluran akar distal, dilakukan preparasi menggunakan $\mathrm{Sx}$, $\mathrm{S} 1$ dilanjutkan \$2 dengan panjang $10 \mathrm{~mm}$, sedangkan untuk saluran akar mesiobukal dan mesiolingual $12 \mathrm{~mm}$. Pengukuran panjang kerja dengan menggunakan apex locator (Propex II, Dentsply) dan foto radiografi. Diperoleh panjang kerja $18 \mathrm{~mm}$ untuk mesiobukal dan lingual serta 16,5 mm untuk saluran akar distal (Gambar 2 dan 3)

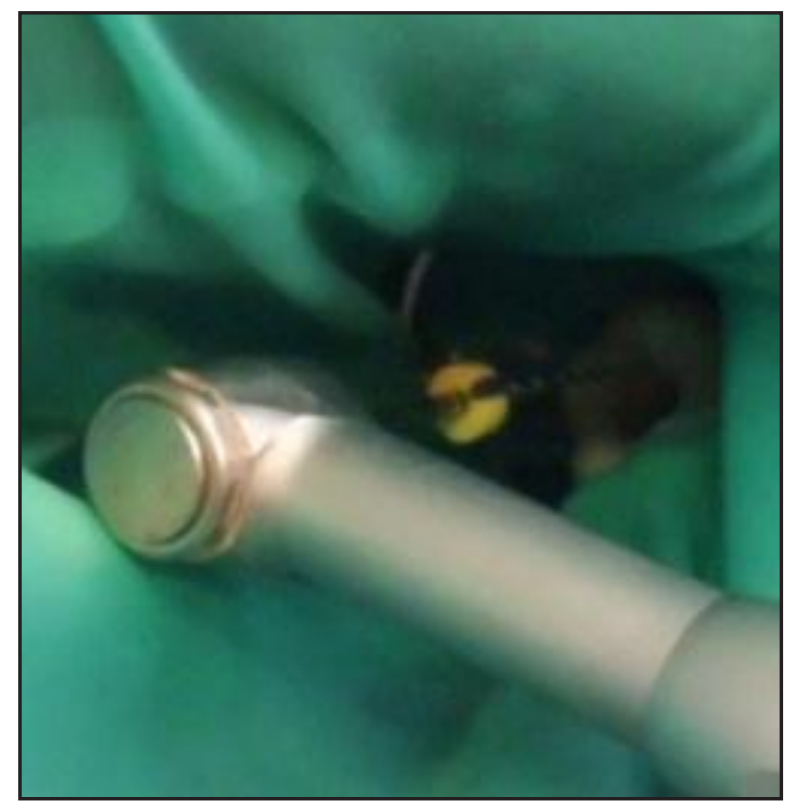

Gambar 2. Preparasi saluran akar dengan teknik crown down sistem rotary.

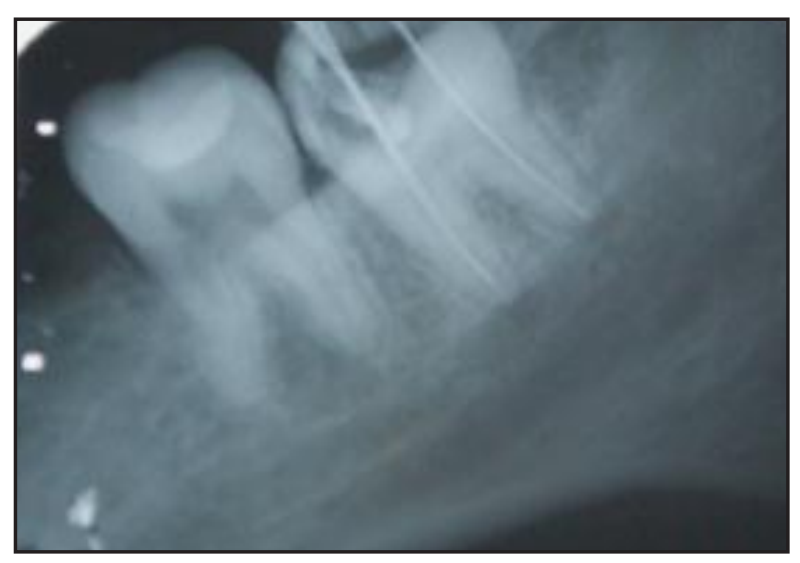

Gambar 3. Pengukuran panjang kerja

Preparasi dengan menggunakan S1 dan S2 sepanjang $16,5 \mathrm{~mm}$ untuk saluran distal dan 18 $\mathrm{mm}$ untuk saluran mesio bukal dan mesio lingual. Selanjutnya tahap finishing yang berakhir di file \#F5 untuk saluran akar distal serta \#F4 untuk saluran mesiobukal dan mesiolingual.Setiap pergantian alat, saluran akar diirigasi dengan EDTA 15\% dan larutan $\mathrm{NaOCl} 2,5 \%$ sebanyak $2,5 \mathrm{ml}$. Setelah preparasi 
saluran akar selesai, saluran akar diirigasi dengan larutan klorheksidin diglukonat $2 \%$ selama 30 detik, kemudian dibilas dengan larutan alkohol $70 \%$. Seluruh saluran akar kemudian dikeringkan dengan paper point.

Pengepasan gutta percha \#F5 selanjutnya, dilakukan untuk saluran akar distal \#F4 untuk saluran akar mesiobukal dan mesiolingual, setelah itu dilakukan pemeriksaan radiograf (Gambar 4). Saluran akar kembali diirigasi menggunakan larutan $\mathrm{NaOCl}$ 2,5\% dan digenangi larutan klorheksidin glukonat $2 \%$ (Bisco) selama \pm 1 menit. Keringkan semua saluran dengan paper point.

Obturasi untuk saluran akar mesio bukal dan mesio lingual dengan menggunakan teknik single cone, sedangkan saluran akar distal dengan teknik single cone kombinasi kondensasi lateral. Gutta percha sesuai file terakhir yang digunakan \#F5 dan \#F4 beserta siler topseal. Mula-mula lentulo yang telah diulasi dengan pasta siler dimasukkan dan diputar dengan handpiece low speed dalam saluran akar, kemudian sepertiga apikal guta perca diulasi siler dan dimasukkan ke dalam saluran akar, dilakukan pada saluran akar satu persatu.Untuk saluran akar distal, dimasukkan finger spreader antara gutta percha dan dinding ditekan kearah apikal. Finger spreader dikeluarkan dan ruang tersedia setelah spreader diambil diisi dengan gutta percha tambahan \#20, ditekan ke apikal lagi sampai spreader tidak dapat masuk setengah dari panjang saluran akar. Setelah

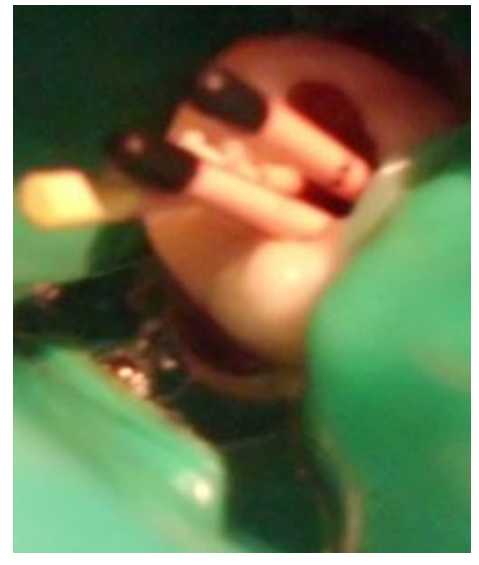

(A)

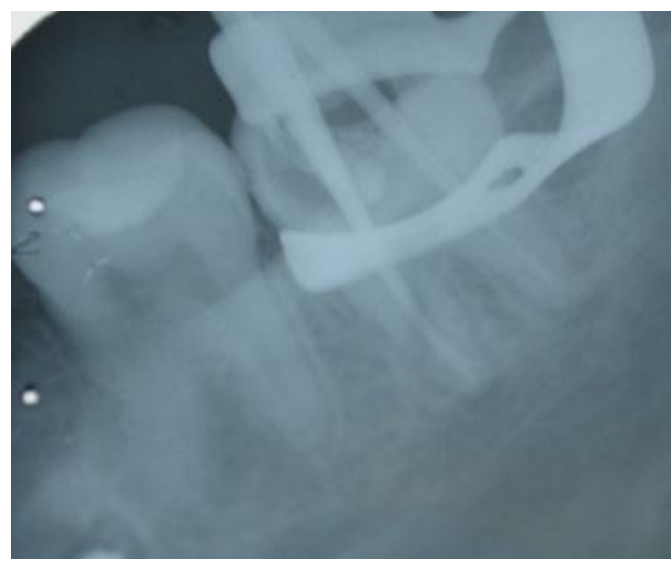

(B)

Gambar 4. Pengepasan gutta percha sesuai panjang kerja A) tampak klinis; B) radiograf.

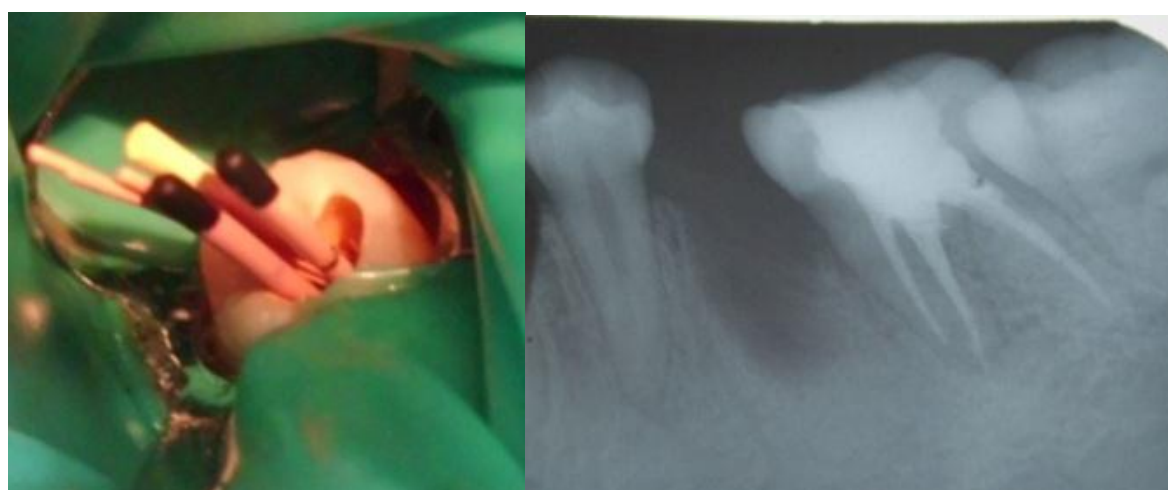

(A)

(B)

Gambar 5. Obturasi saluran akar (A) tampak klinis (B)obturasi tampak hermetis dilihat dari foto roentgen. 
penuh, gutta percha dipotong sebatas orifis dengan plugger yang dipanaskan dan dikondensasi dengan tekanan ringan. Hasil obturasi dikonfirmasi dengan foto radiografis.Kelebihan guta perca dipotong sebatas orifis menggunakan kondensor amalgam yang sudah dipanaskan kemudian dipadatkan dengan fingerplugger hingga pengisian padat. Hasil pengisian saluran akar diperiksa dengan melakukan pemeriksaan radiografis, dan diketahui hasil obturasi hermetis. Kavitas ditutup dengan semen seng phospat sebagai double seal dan ditumpat sementara dengan cavit (Gambar 5)

Kunjungan kedua, 28 Februari 2013, pemeriksaan subjektif: tidak ada keluhan sakit, pemeriksaan objektif: tumpatan sementara masih baik, tes palpasi (-), perkusi (-), dan pemeriksaan radiograf: tumpatan sementara baik, pengisian baik. Kemudian dilakukan penentuan warna menggunakan shade guide untuk restorasi resin komposit, didapat warna $\mathrm{A} 3$ untuk tumpatan resin komposit (Gambar 6).

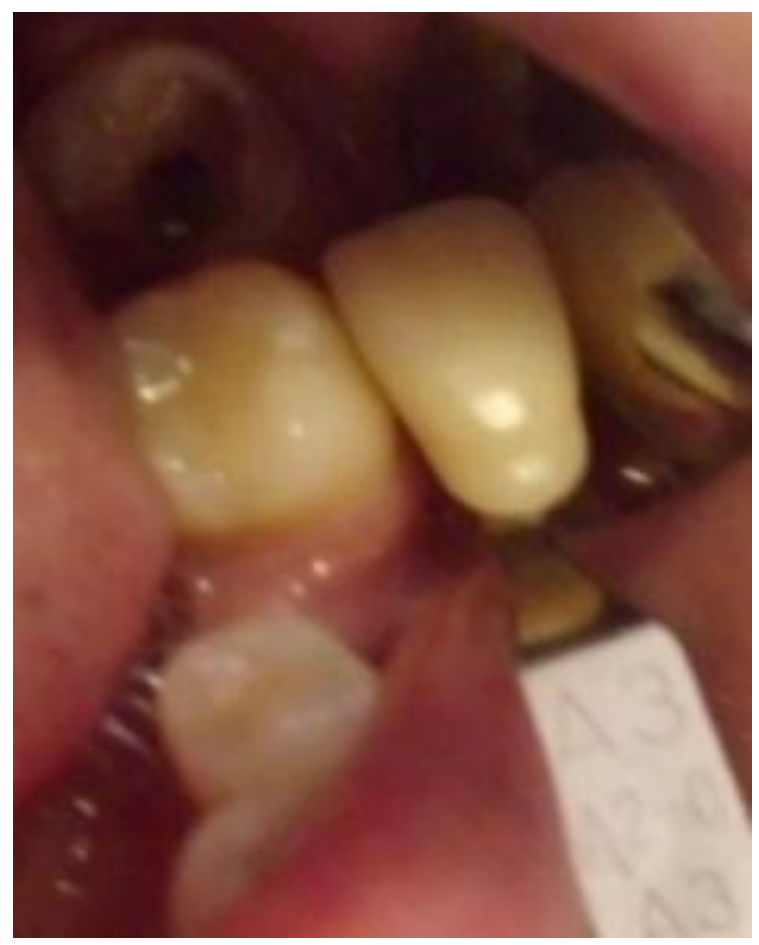

Gambar 6. Pemilihan warna dengan shade guide
Dilanjutkan restorasi resin komposit kavitas kelas II dengan pasak tapered self threading (dentatus screw). Pertama-tama membuang tumpatan sementara (ceivitron) dan tumpatan dasar (semen seng phospat) menggunakan ultrasonic scaler. Preparasi dinding-dinding kavitas dibuat paralel dan dasar kavitas dibuat rata dengan bur fisur silinder ujung datar. Pada semua tonjol gigi dilakukan pemotongan bagian oklusal mengikuti lereng tonjol menggunakan bur intan berbentuk wheel $\pm 1.5 \mathrm{~mm}$. Pembuatan bevel ekstra koronal (outer bevel) dengan bur intan bentuk flame.

Preparasi saluran pasak (pasak utama pada saluran akar distal sedangkan pasak tambahan pada mesiobukal). Menentukan panjang pasak dan peeso reamer terakhir yang akan dipakai. Panjang saluran pasak utama (distal): $12 \mathrm{~mm}$, peeso reamer yang terakhir dipakai no.4, pasak dentatus screw yang dipakai no 3 , gutta perca yang tersisa: 4,5 $\mathrm{mm}$. Sedangkan, panjang saluran pasak tambahan (mesiobukal): $13 \mathrm{~mm}$, peeso reamer yang terakhir dipakai no.4, pasak dentatus screwyang dipakai no 3, gutta perca yang tersisa: $5 \mathrm{~mm}$. Pembuangan gutta perca sesuai dengan panjang saluran pasak dengan cara memasukkan plugger yang dipanaskan kemudian dilanjutkan preparasi menggunakan peeso reamer dari ukuran terkecil sampai peeso reamer terakhir yang telah ditentukan sesuai dengan ukuran pasak yang akan dipakai.

Pengepasan pasak dentatus screw ke dalam saluran pasak. Pasak diletakkan dalam saluran akar sampai kedalaman yang telah dipersiapkan. Pasak diolesi dengan primer Rely X (3M ESPE). Mengaduk semen resin semen (rely $X-3 M E S P E)$, saluran pasak diulas semen dengan lentulo dan tiap pasak diulasi semen yang sama. Pasak dentatus screw didorong perlahan masuk ke dalam saluran akar menggunakan drive khusus, setelah mendapatkan resistensi pasak terjepit pasak diputar 1 putaran dengan hati-hati, kemudian diputar berlawanan arah $1 / 2$ putaran. Sisa semen yang telah mengalir keluar dibersihkan dengan ekskavator (Gambar 7). 


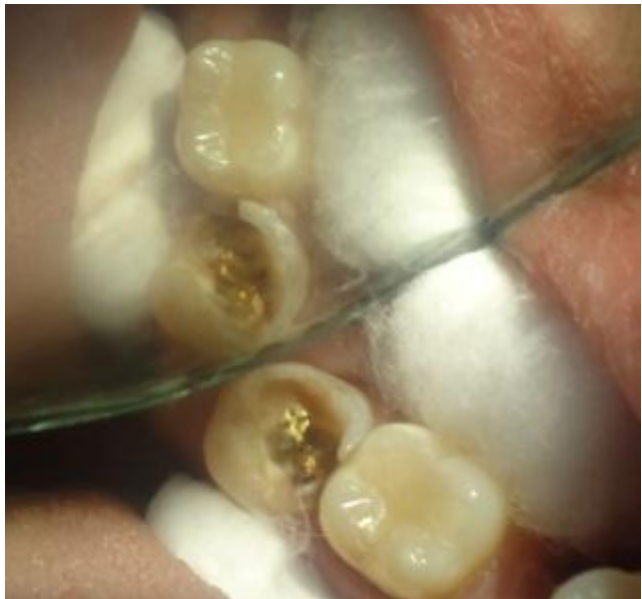

(A)

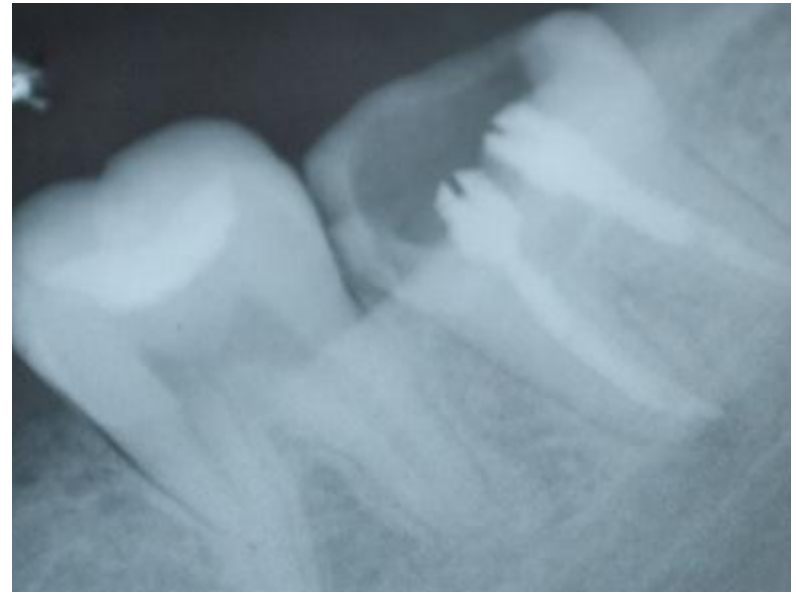

(B)

Gambar 7. Insersi pasak (A) Gambaran klinis pasak utama pada distal dan pasak tambahan pada mesiobukal; (B) Gambaran radiograf.

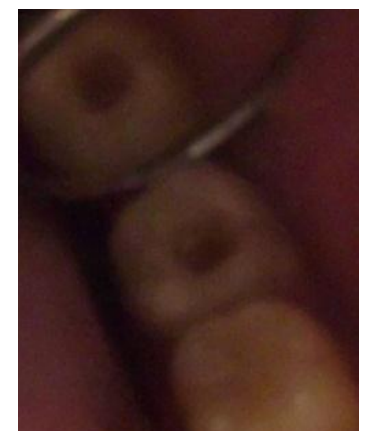

(A)

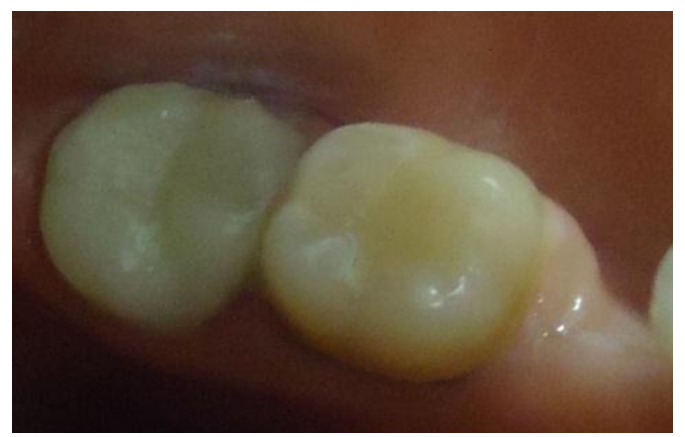

(B)

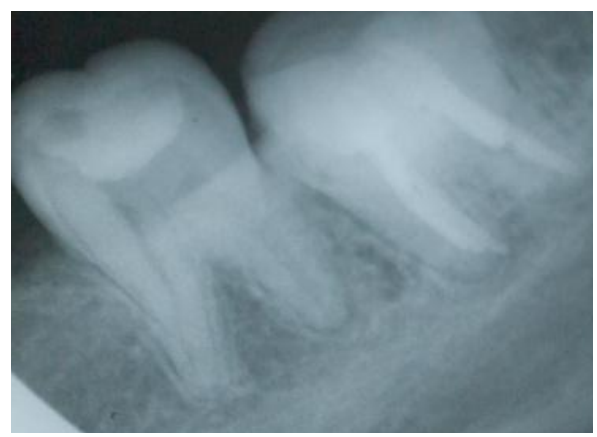

(C)

Gambar 8. (A) Sebelum perawatan (B) Sesudah perawatan (C) Tepi restorasi baik dilihat dari radiografis.

Pemberian etsa pada seluruh permukaan kavitas, didiamkan selama 15 detik kemudian dibilas air dan dikondisikan moist dengan cotton pellet lembab. Bonding (Masterbond, Biodinamica) pada seluruh kavitas dan email yang telah dietsa. ditunggu sesaat, kemudian disemprotkan udara perlahanlahan ke daerah sekitar kavitas, dan dilakukan aktivasi sinar (light curing unit) selama 20 detik. Pemasangan matriks pada sekeliling gigi 38 .

Penumpatan bahan resin komposit pada permukaan kavitas, diaplikasikan secara bertahap. Setiap lapis peletakan bahan resin diaktivasi dengan light curing unit selama 20 detik. Prosedur ini dilakukan sampai seluruh permukaan kavitas terisi penuh dengan bahan resin komposit. Pada tahap ini kontaminasi cairan pada permukaan komposit harus dihindari. Setelah penumpatan resin komposit selesai, dilakukan pengecekan oklusi dengan articulating paper. Finishing restorasi resin komposit menggunakan fine finishing bur. Kemudian dipoles dengan polishing disc (Optidisc, KerrHawe) dan polishing brush (Optishine, KerrHawe). Pasien diinstruksikan untuk kontrol 1 minggu kemudian.

Kontrol restorasi resin komposit kavitas kelas II dengan pasak tapered self threading. Pasien dilakukan pemeriksaan subjektif dan objektif. Pada pemeriksaan subjektif pasien sudah merasa nyaman dan sudah tidak ada rasa sakit. Pemeriksaan objektif: hubungan tepi baik, tidak ada perubahan warna pada gigi, tidak ditemukan garis fraktur pada restorasi maupun gigi (Gambar 8) 


\section{PEMBAHASAN}

Sebelum perawatan saluran akar dilakukan, dokter gigi idealnya mengetahui morfologi ruang pulpa dari gigi yang akan dirawat, terutama pada gigi molar ketiga yang salurannya lebih kompleks. Semua saluran akar harus diakses, dibersihkan, dan dibentuk hingga dapat melakukan pengisian yang hermetis dari seluruh saluran akar. Pembersihan yang tidak lengkap, bentuk corong yang tidak bagus, sertaobturasiyang tidak hermetis dari setiap saluran akar akan menyebabkan kegagalan perawatan saluran. ${ }^{8}$

Laporan kasus ini tidak membahas pentingnya menjaga gigi molar ketiga dengan perawatan endodontik, tapi hanya melaporkan keberhasilan perawatan endodontik pada gigi molar ketiga. Pada gigi molar ketiga sering dilakukan pencabutan, tetapi jika memiliki posisi yang baik, sebaiknya dilakukan perawatan saluran akar. Karena pemeliharaan molar ketiga mungkin dapat dijadikan abutment distal untuk restorasi prostetik di masa depan. Perawatan saluran akar telah diselesaikan dalam satu kunjungan karena ada bukti dalam literatur bahwa perawatan saluran akar satu kunjungan lebih efektif daripada beberapa kunjungan perawatan saluran akar. ${ }^{9}$

Setelah orifis ditemukan, dilakukan preparasi saluran akar teknik crown down dengan menggunakan instrumen rotary. Kelebihan preparasi crown down adalah memudahkan keluar masuknya instrumen dari dan keluar saluran akar, waktu lebih singkat jika dibandingkan dengan menggunakan instrument hand use, memudahkan penetrasi cairan irigasi, memperkecil kemungkinan terjadinya ledge, serta dapat mengurangi kemungkinan terdorongnya debris ke periapeks ${ }^{10}$

Jenis restorasi yang digunakan pasca perawatan saluran akar tergantung kondisi struktur gigi yang tersisa supaya gigi tidak mengalami fraktur. Bahan resin komposit semakin berkembang, mampu memberikan hasil yang cepat, estetis, ekonomis dan mudah dalam memodifikasi bentuk anatomis gigi, serta mudah dikontrol oleh dokter gigi tanpa melibatkan laboratorium atau tekniker. Penumpatan resin komposit secara langsung juga dapat mengurangi kontaminasi mikroorganisme. Restorasi pasca perawatan endodontik dengan pasak tapered self threading menjadi pilihan alternatif karena dapat dijadikan retensi pada tumpatan resin komposit kelas II, khususnya pada gigi molar ketiga.

\section{KESIMPULAN}

Berdasarkan pembahasan, dapat disimpulkan bahwa perawatan saluran akar satu kunjungan lebih efektif untuk menghindari rekontaminasi mikroorganisme saluran akar antar kunjungan. Dan penggunaan teknik rotary instrument pada perawatan saluran akar satu kunjungan dapat mempersingkat waktu, pembersihan lebih sempurna dan memberikan hasil perawatan yang baik. Pada kasus ini digunakan restorasi dengan pasak tapered self threading dengan tumpatan resin komposit kavitas kelas II secara direk. Sebagai saran sebaiknya perawatan saluran akar satu kunjungan sebaiknya menggunakan rotary instrumen supaya diperoleh hasil yang maksimal.

\section{DAFTAR PUSTAKA}

1. Ingle Jl. Endodontic. Ed 5. 2002, Hal 7-9.

2. Kisna VG, Grossman C. Prognostic variable in endodontic treatment. Famdent Practical Dentistry Handbook January-March; 2011. H. 110-7.

3. Vinod MA. Maximum dentistry in minimum visit. The International Journal of Indian Dental Association. 2010; 15-51.

4. Christian de Chevigny. Treatment outcome in endodontics. JOE. 2008 March; 34(3): 258-61.

5. Grossman LI, Oliet S, Rio CED. Ilmu Endodontik dalam praktek. Jakarta: EGC; 1995. H. 82, 190.

6. Douki NZ. Endodontic treatment, how to do it right in one visit? Dental News. 2004; XI(III): 26-29.

7. Walton RE, Torabinejad M. Prinsip dan praktik ilmu endodonsia. Ed 3. Jakarta : EGC; 1996. H. 236-260.

8. Plotino GA. Mandibular third molar with three mesial roots: a case report. JOE. 2008; 34: 224-6.

9. Peters LB, Wesselink PR. Periapical healing of endodontically treated teeth in one and two visits obturated in the presence or absence detectable microorganism. J. Int. Endod. 2002; 35:660-7.

10. Figini L, Lodi G, Gorni F, Gagliani M. Single versus multiple visits for endodontic treatment of permanent teeth. JOE. 2007; 10:112-115. 